\title{
Recent observations on the serology of syphilis*
}

\author{
A LUGER, B SCHMIDT, I SPENDLINGWIMMER, AND F HORN \\ From the Department of Dermatology, City Hospital, Vienna-Lainz, and the Ludwig Boltzmann Institute, \\ Vienna
}

SUMMARY Routine screening of 404742 sera by the automated micro-haemagglutination assay (AMHA-TP) and the Venereal Disease Research Laboratory (VDRL) test showed that 9848 specimens gave a reactive result to one of the three assays. Reactive results were confirmed by the fluorescent treponemal antibody absorption (FTA-ABS) test. The possibility of false-positive results varied from $0 \cdot 04-0 \cdot 38 \%$ of all specimens or from $1 \cdot 7-15 \cdot 7 \%$ of reactive sera. The VDRL test failed to detect reactivity in $56 \cdot 54 \%$ of sera from patients who had previously been infected with Treponema pallidum.

The importance of routine testing by the AMHA-TP is illustrated by the detection of four patients with mesaortitis and two with active neurosyphilis among a selected group of 54 patients who had non-reactive results to the VDRL test. Testing of cerebrospinal fluid specimens by the AMHA-TP test produced more specific results than by the other two tests.

\section{Introduction}

Recent research into the serology of syphilis has concentrated on the identification of specific IgM and IgG antibodies against Treponema pallidum. The basic fluorescent treponemal antibody absorption (FTA-ABS) test however allows a margin of error ${ }^{1-5}$ which may be $6 \cdot 8-10 \cdot 7 \%,,^{6} 7 \%,{ }^{7}$ or $37 \cdot 2 \%,{ }^{8}$ The sources of error may be non-specific group antibodies, the use of an inefficient sorbent, changes on the cell surface due to lyophilising of $T$ pallidum, and to other factors. ${ }^{4-12}$

The occurrence of $T$ pallidum-specific antibodies of the IgM class seems to indicate early or active syphilitic infection whereas their disappearance after antibiotic treatment may prove a cure. $.^{1011} 13-16$

The methods used in these investigations are so far not precise enough for definite conclusions. ${ }^{11} 1718 \mathrm{An}$ improvement in methods is taking place in several research centres and promises a better approach in a few years.

The results of the $T$ pallidum haemagglutination assay (TPHA) have been assessed by many workers in the last few years. ${ }^{19-37}$ This test appears to be the

*Paper presented at the Spring Meeting of the MSSVD at Leeds, 1978

Address for reprints: Professor A Luger, Krankenhaus der Stadt Wien Lainz, A-1130 Vienna, Austria

Received for publication 18 May 1978 most sensitive, specific, and economical method for the serodiagnosis of syphilis. It indicates the presence of IgM and IgG antibodies against $T$ pallidum and may therefore become reactive before any other test. ${ }^{23-25} 37$

The micro-haemagglutination assay (MH-TP) and especially the automated version of this procedure (AMHA-TP) is most valuable for screening purposes. ${ }^{12} 1923-252738-43$ The common trend in screening is towards the application of the AMHA-TP and a lipoidal antigen test, the Venereal Disease Research Laboratory (VDRL) test, the rapid plasma reagin (RPR) test, ${ }^{24} 2740$ the reagin serum (RST) test, ${ }^{43}$ and others. At present however the VDRL test is the best standardised test in use based on 25 years' experience.

\section{Methods}

The use of the AMHA-TP test and the VDRL test for screening was first suggested in 1972 by Luger and Spendlingwimmer. ${ }^{25}$ Since that time, 404742 sera have been examined during a period of six years at the Department of Dermatology in the City Hospital Vienna-Lainz and evaluated by the LudwigBoltzmann Institute of Dermatovenereological Serodiagnosis. All samples were received from hospitals, outpatient dispensaries, or the central health office in Vienna. The sera were tested routinely by the AMHA-TP and by the VDRL test. Reactive results were checked by the FTA-ABS test. The tests were performed as described. ${ }^{10} 2427$ 


\section{Results and comments}

The results of sera examined between 13 March 1972 and 30 April 1978, as well as of the reactivity to the three tests, are given in Table I. A total of 394894 samples were non-reactive to the AMHA-TP and to the VDRL test and were therefore not investigated further. Of the remainder, 9848 sera were reactive to one or both of the two screening tests and the results were checked by the FTA-ABS test.

TABLE I Results of serological tests on 404742 sera

\begin{tabular}{|c|c|c|c|c|c|}
\hline \multicolumn{4}{|c|}{ Reactivity to following tests } & \multirow{2}{*}{$\begin{array}{l}\% \text { of } \\
\text { total No } \\
\text { reactive to } \\
l / 3 \text { tests }\end{array}$} & \multirow{2}{*}{$\begin{array}{l}\% \text { of } \\
\text { total } \\
\text { No } \\
\text { examined }\end{array}$} \\
\hline $\begin{array}{l}A M H A- \\
T P\end{array}$ & $\begin{array}{l}F T A- \\
A B S\end{array}$ & $V D R L$ & $\begin{array}{l}\text { No of } \\
\text { sera }\end{array}$ & & \\
\hline+ & - & - & 1377 & $13 \cdot 98$ & $0 \cdot 34$ \\
\hline+ & - & - & 4226 & $42 \cdot 91$ & $1 \cdot 04$ \\
\hline+ & + & + & 3248 & $32 \cdot 98$ & 0.80 \\
\hline+ & - & + & 95 & 0.97 & 0.02 \\
\hline- & + & + & 73 & 0.74 & 0.02 \\
\hline- & - & + & 829 & $8 \cdot 42$ & $0 \cdot 21$ \\
\hline \multirow{4}{*}{\multicolumn{3}{|c|}{$\begin{array}{l}\text { Total No reactive to } 1 / 3 \text { tests } \\
\text { Total No non-reactive to } \\
\text { AMHA-TP/VDRL } \\
\text { Grand total }\end{array}$}} & 9848 & $100 \cdot 00$ & $2 \cdot 43$ \\
\hline & & & & & \\
\hline & & & 394849 & & $97 \cdot 57$ \\
\hline & & & 404742 & & $100 \cdot 00$ \\
\hline
\end{tabular}

+ Reactive - non-reactive

Of the 1377 sera showing reactive results to the AMHA-TP but non-reactive results to the FTA-ABS test and the VDRL test, a few may have occurred in patients at the beginning of the infection (before the third week) but, as far as could be traced, they were mainly found in patients who had contracted syphilis many years previously, were adequately treated, and were probably cured. Some sera came from old people who denied having had syphilis.

No history was obtainable from most of the donors. Further investigations to try to elucidate the reasons for an isolated reactive result to the AMHATP were undertaken but these results could have been non-specific (false-positive results) in several cases.

The results of the 4226 specimens which were reactive to the AMHA-TP and to the FTA-ABS test but not to the VDRL test indicate that the donors had syphilis, but the non-reactivity of the VDRL test suggests that the infection had occurred many years previously, had been treated successfully, or had disappeared spontaneously.

Since 3248 sera were reactive to the AMHA-TP, to the FTA-ABS, and to the VDRL tests, there can be no doubt the donors all had syphilis. Ninety-five specimens were reactive to the AMHA-TP and to the VDRL test but non-reactive to the FTA-ABS test, and 73 specimens were non-reactive to the AMHATP test but reactive to the FTA-ABS and VDRL tests. These latter two groups comprise results which showed either false-reactivity or false non-reactivity in one of the two tests using treponemal antigens. The results for the 829 sera which were non-reactive to the AMHA-TP and the FTA-ABS test but reactive to the VDRL test can be considered biological falsepositive reactions.

The possibility of obtaining false results by the above method of screening may vary from 1.7 to $15.7 \%$ of the reactive samples and from 0.04 to $\mathbf{0 . 3 8 \%}$ of all sera examined. The first figure constitutes an absolute minimum, the last an improbable maximum. The rate of specific reactivity of $1 \cdot 84 \%$ (minimum) seems to be high but this is due to the selection of patients for serum antibody tests in most of the hospitals and dispensaries.

\section{NON-REACTIVE RESULTS IN SELECTED GROUP}

Results were obtained from 53 patients who were reactive to the AMHA-TP as well as to the FTA-ABS tests but non-reactive to the VDRL test. These patients were asked to attend for clinical examination. Of these, 10 had a history of a previous infection and had been adequately treated. Of the 43 who did not know that they had once had syphilis, 37 had no symptoms, four had mesaortitis with aortic diameters ranging from 40 to $50 \mathrm{~mm}$ on their radiographs (only one had attended the hospital because of cardiac complaints, one attended because of a leg ulcer, one had hepatic cirrhosis, and one had a keratoacanthoma), and two had changes of active neurosyphilis in the cerebrospinal fluid (one had tabes dorsalis and the other, clinically asymptomatic meningovascular syphilis with focal signs on electroencephalographs). Both these latter patients attended the department of urology, the first because he had difficulties of micturition (early tabetic paralysis of the bladder) and the other because of vague urological complaints. Late syphilis was discovered in all six patients by routine serum antibody tests.

These investigations could be performed on only $53(1 \cdot 25 \%)$ of 4226 patients and concern exclusively patients of the City Hospital, Lainz. These observations were therefore of a highly selected group and are not at all representative, although the results emphasise the importance of routine serological testing with the AMHA-TP instead of the VDRL test.

\section{COMPARATIVE EVALUATION OF TESTS}

In a comparative evaluation of the three tests (Table II), the agreement between the AMHA-TP and FTAABS test was $82 \cdot 87 \%$ of the reactive samples or $99.61 \%$ of all sera (reactive plus non-reactive results); agreement between the AMHA-TP and the VDRL test was $33 \cdot 95 \%$ or $98 \cdot 39 \%$ respectively and 
TABLE II Comparative evaluation of results to three tests

\begin{tabular}{|c|c|c|c|c|c|c|c|c|c|c|c|c|}
\hline \multirow{4}{*}{$\begin{array}{l}\text { Reactivity } \\
\text { to following } \\
\text { tests }\end{array}$} & \multicolumn{12}{|c|}{ Reactivity to following tests } \\
\hline & \multicolumn{6}{|c|}{$F T A-A B S$} & \multicolumn{6}{|c|}{$V D R L$} \\
\hline & \multicolumn{2}{|l|}{-} & \multicolumn{2}{|l|}{+} & \multicolumn{2}{|l|}{ Total } & \multicolumn{2}{|l|}{-} & \multicolumn{2}{|l|}{+} & \multicolumn{2}{|l|}{ Total } \\
\hline & No & $\%$ & No & $\%$ & No & $\%$ & No & $\%$ & No & $\%$ & No & $\%$ \\
\hline $\begin{array}{c}\text { VDRL } \\
- \\
+ \\
\text { Total }\end{array}$ & $\begin{array}{l}924 \\
924\end{array}$ & $\begin{array}{l}10.91 \\
10.91\end{array}$ & $\begin{array}{l}4226 \\
3321 \\
7547\end{array}$ & $\begin{array}{l}49 \cdot 89 \\
39 \cdot 20 \\
89 \cdot 09\end{array}$ & $\begin{array}{l}4226 \\
4245 \\
8471\end{array}$ & $\begin{array}{r}49 \cdot 89 \\
50 \cdot 11 \\
100 \cdot 00\end{array}$ & & & & & & \\
\hline $\begin{array}{l}\text { AMHA-TP } \\
- \\
+ \\
+ \\
\text { Total }\end{array}$ & $\begin{array}{l}1472 \\
1472\end{array}$ & $\begin{array}{l}16 \cdot 32 \\
16 \cdot 32\end{array}$ & $\begin{array}{r}73 \\
7474 \\
7547\end{array}$ & $\begin{array}{r}0 \cdot 81 \\
82 \cdot 87 \\
83 \cdot 68\end{array}$ & $\begin{array}{r}73 \\
8946 \\
9019\end{array}$ & $\begin{array}{r}0 \cdot 81 \\
99 \cdot 19 \\
100 \cdot 00\end{array}$ & $\begin{array}{l}5603 \\
5603\end{array}$ & $\begin{array}{l}56.90 \\
56.90\end{array}$ & $\begin{array}{r}902 \\
3343 \\
4245\end{array}$ & $\begin{array}{r}9 \cdot 15 \\
33 \cdot 95 \\
43 \cdot 10\end{array}$ & $\begin{array}{r}902 \\
8946 \\
9848\end{array}$ & $\begin{array}{r}9 \cdot 15 \\
90 \cdot 85 \\
100 \cdot 00\end{array}$ \\
\hline
\end{tabular}

between the FTA-ABS test and the VDRL test $39 \cdot 2 \%$ or $98 \cdot 72 \%$ respectively. The somewhat better agreement between the FTA-ABS and VDRL tests compared with the AMHA-TP and VDRL test can be explained by the fact that the FTA-ABS test sometimes (in primary and in early secondary syphilis) returns earlier to non-reactivity after adequate treatment than does the AMHA-TP.

The importance of the use of the AMHA-TP for screening is shown by the fact that the VDRL test alone failed to indicate reactivity in $4226(56 \cdot 54 \%)$ of 7474 sera which were reactive to both the AMHA-TP and the FTA-ABS test and thus came from persons who were infected at one time with $T$ pallidum. The significance of detecting specific antibodies in the sera of these patients has been emphasised by the serological results of the 53 selected patients already mentioned.

\section{REACTIVITY OF CSF SAMPLES}

Little is known about the comparative reactivity of serum and cerebrospinal fluid (CSF) to the haemagglutination assay. Specimens from 238 donors were examined. The AMHA-TP (micro-method) was performed using serum and the TPHA (macro-method) using CSF. There was no difference in the method of examination of serum and CSF by the other two tests (FTA-ABS and VDRL).

\section{COMPARATIVE EVALUATION}

A comparative evaluation of the reactivity to the three tests on serum and CSF is summarised in Table III. The sera of two patients were non-reactive but the CSF was reactive to the AMHA-TP test. Both patients had clinical features of tabes dorsalis, one with markedly increased CSF protein $(0.83 \mathrm{~g} / \mathrm{l})$ and a normal cell count $(1 / \mathrm{ml})$, the other with slightly

TABLE III Comparative evaluation of serological test results for serum and cerebrospinal fluid

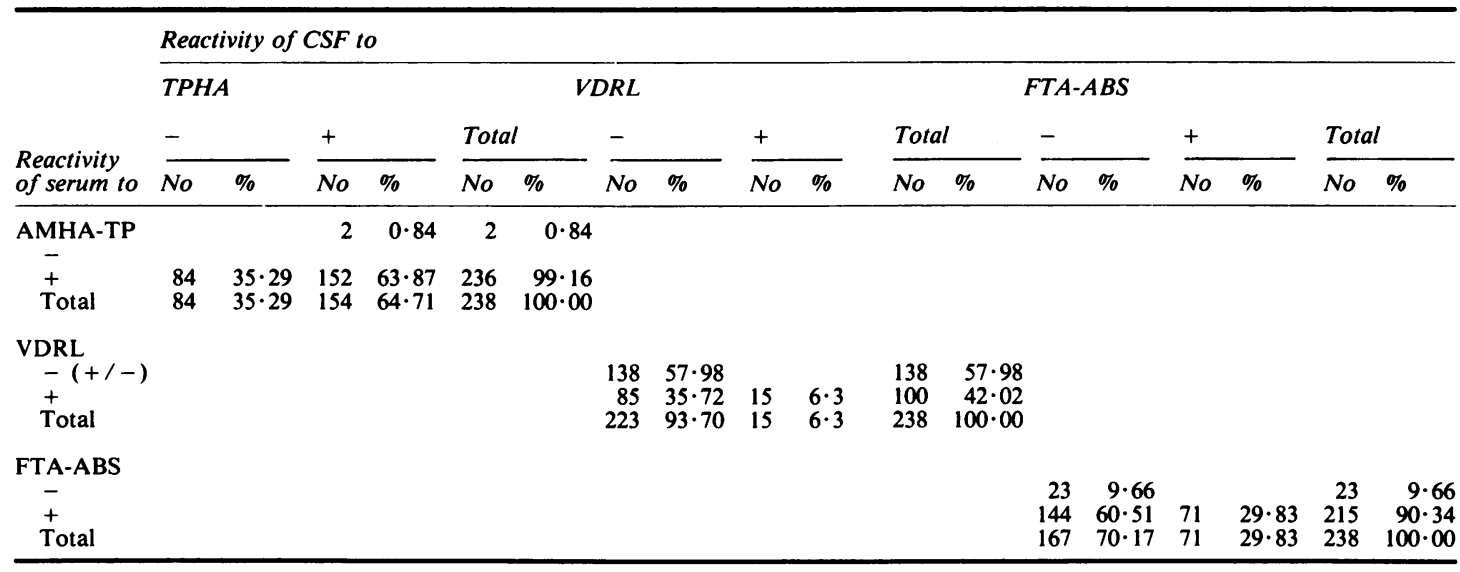

+ Reactive; +/ - weakly reactive; - non-reactive 
increased protein and a cell count of $4 / \mathrm{ml}$. The serum and CSF of the first patient were both reactive to the haemagglutination test at a dilution of $1 / 40$, which is a reactive result for CSF but a non-reactive result for serum. Both the serum and the CSF were nonreactive to the FTA-ABS and VDRL tests. The serum of the second patient was non-reactive to the haemagglutination assay and to the VDRL test; the FTA-ABS test result was borderline on several different attempts with material from the same sample whereas the CSF was reactive to the haemagglutination tests at a dilution of 1/40 and nonreactive to the FTA-ABS and VDRL tests.

The antibody titre, as detected by the AMHA-TP, was equally high in CSF and serum, which indicates that these antibodies have not necessarily come from the serum since the protein values did not indicate a breakdown of the blood-CSF barrier; thus they may have been produced within the cerebrospinal system.

Of the donors who were sero-reactive to the haemagglutination assay, $65 \cdot 3 \%$ were also CSFreactive to the same test. The figures for the FTAABS and VDRL tests were $33 \%$ and $15 \%$ respectively. This seems to indicate that the haemagglutination method is twice as sensitive as the FTAABS test and four times as sensitive as the VDRL test for CSF.

In a comparative quantitative evaluation of the results of the haemagglutination assay higher titres occurred in CSF in $11(4.62 \%)$ of 238 samples and in serum in $224(94 \cdot 12 \%)$ of 238 samples. The VDRL titres were all higher in serum than in CSF; this suggests that the haemagglutination assay may sometimes be more sensitive in CSF than in serum when quantitatively evaluated. Further research is however necessary to improve the technique and reduce the margin of error.

\section{References}

1. Baertschy D, Golubjatnikov R, Stedman $M$, Inhorn LS. Serologic study of specimens with borderline FTA-ABS test reactivity. Health Lab Sci 1977; 14: 177-82.

2. Burns RE. Spontaneous reversion of FTA-ABS test reactions. JAMA 1975; 234: 617.

3. John JF, Cuetter AC. Spinal syphilis: the problem of fluorescent treponemal antibody in the cerebrospinal fluid. South Med J 1977; 70: 309-11.

4. Shin DH, Kass MA, Kolker AE, Becker B, Marr JJ, Bell CE. Positive FTA-ABS tests in subjects with corticosteroid-induced uveitis. Am J Ophthalmol 1976; 82: 259.

5. Zajac $W$, Pucilo $K$, Zaremba A. A serological analysis of weakly positive and doubtful results of tests for syphilis in elderly persons. Przegl Dermatol 1975; 62: 205-9.

6. Leitgeb G, Cervetti O, Giovannini E, Sartoris S, Goitre M. Studio della lue primaria. G Ital Derm 1975; 110: 83-92.

7. Drew FL, Sarandria JL. False-positive FTA-ABS in pregnancy. J Amer Vener Dis Assoc 1975; 1: 165.
8. Dans PE, Judson FN, Larsen SA, Lantz MA. The FTA-ABS test: a diagnostic help or hindrance. South Med J 1977; 70: 312-5.

9. Kiraly $K$, Kramer M. Die entwicklung der serologischen syphilis-diagnose während der letzten 30 Jahre. Borgygy Vener Szle 1976; 52: 10-21.

10. Luger A, Schmidt B, Spendlingwimmer I. Quantitative evaluation of the FTA-ABS-IgM and VDRL test in treated and untreated syphilis. Br J Vener Dis 1977; 53: 287-91.

11. Wilkinson AE, Rodin P. IgM-FTA test in syphilis in adults; Its relation to clinical findings. Br J Vener Dis 1976; 52: 219-23.

12. Luger A. Recent developments in the serological diagnosis of syphilis. Proceedings of the XV International Congress of Dermatology. Amsterdam; Excerpta Medica, 1978.

13. Ghinsberg R, Grunbaum BW, Blumstein G. Rapid detection of specific antitreponemal antibodies by counterimmunoelectrophoresis using an extract of Treponema pallidum. Isr J Med Sci 1977; 13: 557-60.

14. Müller F. Modellversuche zur wirkung von IgM und IgG antikorpern auf die reaktionen des Treponema pallidum hämagglutinations (TPHA) testes. Hautarzt 1976; 27: 26-9.

15. Müller $F$. Serodiagnostik aus der sicht des immunologen. Hautarzt 1977; 28: 167-72.

16. Wilkinson AE. Some aspects of research of syphilis. Serological evidence of activity of the disease. In: Catterall RD, Nicol CS, eds. Sexually Transmitted Diseases. London: Academic Press, 1976; 214-8.

17. Kerl H, Bayer U, Turek TD. Beurteilung und klinische bedeutung des Treponema pallidum hämagglutinations (TPHA) testes in der syphilisdiagnostik. Z Hautkr 1976; 51: 718-26.

18. Kaufman RE, Olansky DC, Wiesner PJ. The FTA-ABS (IgM) test for neonatal congenital syphilis. A critical review. $J$ Amer Vener Dis Assoc 1975; 1: 79.

19. Adler MW, Belsey EM, O'Connor BH, Catterall RD, Miller DL. Facilities and diagnostic criteria in sexually transmitted disease clinics in England and Wales. Br J Vener Dis 1978; 54: 2-9.

20. Alessi E, Scioccati L. Test di emoagglutinazione treponemica (TPHA). Validità del micrometode esognito con le diluizioni dei seri 1/20-1/40. Boll Ist Seiroter Milan 1977; 56: 102-7.

21. Kiraly K, Prerau H. Evaluation of the Treponema pallidum haemagglutination (TPHA) test for syphilis on "problem sera". Acta Derm Venereol (Stockh) 1974; 54: 303-10.

22. Lesinski J, Krach J, Kadziewicz E. Specificity, sensitivity, and diagnostic value of the TPHA test. Br J Vener Dis 1974; 50: 334-40.

23. Luger A. Geschlechtskrankheiten. Hautzart 1977; Suppl 2, $12-21$.

24. Luger A. Immunologie der syphilis. In: Korting GW, ed. Dermatologie in Praxis und Klinik. Stuttgart: G Thiemi, (in press).

25. Luger A, Spendlingwimmer I. Der Treponema pallidum hämagglutinations (TPHA) test. Wien Klin Wochenschr 1972; 84: $657-63$.

26. Luger A, Spendlingwimmer I. An appraisal of the Treponema pallidum haemagglutination (TPHA) test. Br J Vener Dis 1973; 49: $181-2$.

27. Luger A, Spendlingwimmer I. Der automatisierte mikrohämagglutinations test mit Treponema pallidum antigen (AMHA-TP test). Hautarzt 1974; 25: 238-44.

28. Luger A, Spendlingwimmer I, Zips A, Ogris E, Hawlicek F Puhringer R. Das verhalten der reaktivitat in syphilis serologischen untersuchungsmethoden. Z Hautkr 1976; 51: 718-26.

29. Manikowska-Lesinska W, Linda B, Szymska K, Zajac W. Studies on the method of the TPHA test. Przegl Dermatol 1975; 62: 663-9.

30. Muller F, Luger A. Treponemen-spezifische immunodiagnostik der syphilis und deren normierung. $Z$ Hautkr 1976; 51: 643-51.

31. O'Neill P. A new look at the serology of treponemal disease. Br J Vener Dis 1976; 52: 296-9.

32. Robertson DHH, McMillan A, Young H, Henrichsen C. Clinical value of the Treponema pallidum haemagglutination test. Br J Vener Dis 1975; 51: 79-82.

33. Schröter R. Die serodiagnostik der syphilis. Ther Umsch 1975; 33: 9-15.

34. Shore $\mathbf{N}$. Haemagglutination tests and related advances in serodiagnosis of syphilis. Arch Dermatol 1974; 109: 854-7. 
35. Willcox RR. Perspectives in venereology. Abstr Hyg 1976; 51: 237-92.

36. Yogeswari L, Sowmini CN. Treponema pallidum haemagglutination test (TPHA) for the specific serodiagnosis of syphilis. Indian J Dermatol 1974; 40: 185-92.

37. Jephcott AE, Beveridge MAM, Sequeira PJL. Early TPHA response in primary syphilis. Br. J Vener Dis 1977; 53: 147.

38. Kern A. Notwendigkeit und kriterien einer zeitgemäßen routine such serodiagnostik der syphilis. Medicamentum (Berlin) 1975; 16: $34-41$.

39. Kippax PW, Okoye RC. Screening for treponemal infection. Br J Vener Dis 1975; 51: 144.

40. Luger A, Spendlingwimmer I, Horn F. Der Treponema pallidum hamagglutinations test als suchreaktion. Ther Umsch 1976; 33: 16-9.

41. Young $\mathrm{H}$, Henrichsen $\mathrm{C}$, Robertson DHH. Treponema pallidum haemagglutination test as a screening procedure for the diagnosis of syphilis. Br J Vener Dis 1976; 50: 341-6.

42. Rudolph $\mathrm{AH}$. The microhaemagglutination assay of Treponema pallidum antibodies (MHA-TP). J Amer Vener Dis Assoc 1976; 3: 3-8.

43. Black DA, Ray PE, Therreli BL. Qualitative evaluation of the reagin screen test. J Clin Microbiol 1976; 4: 16.

44. Bowszyc J. The cerebrospinal fluid in syphilis in the aspect of immunological studies. Przegl Dermatol 1975; 62: 365-71.

45. Duncan WP, Kuhn USG. Further studies of the fluorescent treponemal antibody cerebrospinal fluid (FTA-CSF) test with a monospecific anti-IgM-conjugate. Br J Vener Dis 1973; 49: 487-90.

46. Vakovleva N. A quantitative immunofluorescence method with the cerebrospinal fluid from patients with different forms of syphilis. Vestn Dermatol Venereol 1975; 2: 31-6.

47. Zajac W, Krach-Karczmarczyk J, Pucilo K. Diagnostic value of serological tests in the cerebrospinal fluid. Przegl Dermatol 1973; 63: 319-23.

48. Catterall RD. Neurosyphilis. Br J Hosp Med 1977; 17: 585-604.

49. Lancet. Editorial: Routine tests for syphilis on cerebrospinal fluid. Lancet 1977; 2: 595. 